\title{
Study on the Methods and Effective Way to Improve the Practical Ability of Students in Modern Educational Technology Major
}

\author{
Xiamsiya Mamtimin ${ }^{1, \text { a }}$ \\ ${ }^{1}$ Faculty of Mathematics and Information, Teachers Collage of Hotan, XinJiang 848000, P.R. China
}

Keywords: Practical Ability; Improve Method; Modern Educational Technology

\begin{abstract}
With economic development and progress of science and technology, information technology is fully penetrated in various fields, the study field of educational technology and practice of expanding territory, from the past little education (schooling) towards the big education (information technology education services) stage, society increasingly need to master information technology, has a strong practical ability, and can continue to learn new ideas and technology, education and consciously used in a variety of situations technical professionals. For social needs, enhance educational technology students practical ability is particularly important.
\end{abstract}

\section{Introduction}

In the past, the mountain in content technology is not high, usually educational technology go to education means and methods, but since the 20th century, new science, new technology in the education of small break, a widely used technology in the educational process plays increasingly important role, Diao gradually formed a fourth influence teaching structure other than the classroom, students, teaching materials to be hanging factors) media (actually includes instructional media, resources and the environment). At the same time, in order to educate the fourth cable for the study of subjects) Educational Technology (also known as AVE) came into being. With the emergence of educational technology is educational and production, a discipline with scientific and technological progress and development; it is based on a variety of new technology in educational activities for the study; therefore educational technology is a practical , applied strong discipline. This requires that educational technology professionals have a strong practical ability and tireless spirit of continuous learning of new technologies, the application of new technologies. So for Educational Technology Training of educational technology professional, we should cultivate professional practice in an important position. Currently, multimedia technology and cloud \# computer network appears rapid development, multimedia computer popularity, especially in the campus network, the Internet's development and introduction changed the teaching environment, abundant teaching resources, which greatly promoted the development of educational technology the formation of new learning environments and resources to a variety of network-centric media combine in practice the current social need to understand both the educational theory, but also for teaching and learning provided a meter under the guidance of teaching theory and learning theory, development, management and application gathers educational theory and educational skills in one, able to guide the various disciplines of modern educational theory of teaching and learning and multimedia technology as the core of modern educational technology combine education and technical personnel.

\section{The Concept of Practical Ability}

Practice and practice are inseparable, the core of the development of practice is to develop practical ability of practitioners. Practice is outside the body and the ability to achieve a particular object in a particular environment; therefore, human development first is the development of human practice, the practice of human development is primarily the development of human practice ability. It can also be said that the development process is the practical ability of human life practice course. All external, objective human activity can be called practice. In other words, practice is the main human activities are the primary way people self-generation is the largest real people live. Practice is the 
manifestation of man's social nature, human nature is manifested through practical activities.

Table 1 IT teacher's ability to scale structure

\begin{tabular}{|l|l|}
\hline Dimensions & Related knowledge and skills \\
\hline The ability of teaching & $\begin{array}{l}\text { Education, psychology, pedagogy courses, IT } \\
\text { courses and teaching skills related to knowledge }\end{array}$ \\
\hline $\begin{array}{l}\text { Media and applications and resources } \\
\text { Capacity Development }\end{array}$ & $\begin{array}{l}\text { Multimedia courseware design and } \\
\text { development, teaching web design and } \\
\text { development, multimedia technology, the } \\
\text { program set Design, artificial intelligence } \\
\text { technology-related knowledge and skills }\end{array}$ \\
\hline $\begin{array}{l}\text { Theory of learning and teaching instructional } \\
\text { design }\end{array}$ & $\begin{array}{l}\text { Educational communication, instructional } \\
\text { design, information technology and curriculum } \\
\text { integration of theory and practice, computer } \\
\text { technology-related knowledge and skills }\end{array}$ \\
\hline $\begin{array}{l}\text { Ability of Educational Technology Research } \\
\text { Methods of teaching and research }\end{array}$ & $\begin{array}{l}\text { Education statistical measurement, education, } \\
\text { information processing-related knowledge and } \\
\text { skills }\end{array}$ \\
\hline
\end{tabular}

Practical ability is the individual ability to solve practical problems for students, mainly refers to individual students to absorb, integrate resources to support education and individual basis tomb resources, adapt to social life, to solve basic practical problems, participation in social life and a practice, and promote personal growth, self-improvement practice ability of dominant position. Has an explicit material, process can be observed and / ji and reality situations are closely related. The real problem is complex situations, unpredictable. To solve practical problems, the method is not unique, the process also has a personal color. Therefore, the ability to solve real problems are very complex and difficult to measure. At home, the ability to practice in a broad and narrow sense, narrow sense refers to the ability of experimental, hands-on ability, skills, sexual ability and other physical activity, and can be broadly understood as the practical ability is in life or work to solve practical problems demonstrated by the comprehensive ability, people living and working are essential: - mortar is not taught by the book obtained, but hone in accumulation of life and practice gained; it is difficult to use Juanmian tests to measure, can only be assessed by practice performance; it is an important factor affecting the success of their career.

\section{The Situation of Practical Ability}

Personnel training in educational technology Recently, some schools are inadequate school system, curriculum more casual, the lack of scientific and normative, mostly focused on the students to develop professional technical courses while ignoring basic theory, ignoring the effective combination of education and technology, etc. phenomenon, these are not conducive to training with a strong information technology and education based integrated talent, so students in the job market> almost no features, the lack of a strong non-members on behalf of. In addition, as the early creation of educational technology, primarily to meet the needs of educational institutions EDUCATIONAL talent, too much of the coated dagger of the normal color, narrow field of vision, so most college graduates in the main flow of primary and secondary schools. 
Table 2 Education Majors Oral Language Survey

\begin{tabular}{|c|c|c|c|}
\hline topic & Reply & Quantity & percentage(\%) \\
\hline Use of dialect situation & Extensive use & 0 & 0 \\
& Partially used & 43 & 10.1 \\
& Individual words & 148 & 34.8 \\
& Never & 23 & 55.1 \\
\hline Exact wording case & Very accurate & 30 & 7.1 \\
& accurate & 255 & 60 \\
& Less accurate & 140 & 32.9 \\
& Inaccurate & 0 & 0 \\
& appear frequently & 42 & 9.9 \\
\hline It appears stuck & & & 81.2 \\
situation & Occasionally & 345 & 8.9 \\
\hline Explain whether attract & No & 35 & 24.7 \\
students & Throughout & 105 & 75.3 \\
& occasionally & 320 & 0 \\
\hline
\end{tabular}

Japanese standard curriculum is to achieve education and training day target platform, reflecting the personnel training specifications and features. Any kind of educational philosophy must rely with suitable curriculum be implemented. In fact a broad array of information and data, human knowledge doubled every two years, while the case of our class and teaching will not double the speed, we should be taught to students at any time may be updated out knowledge or should I develop their creativity private critical thinking. professional orientation is not clear, the system will lead to curriculum set cloud BU problem is not conducive to the cultivation practice ability of students. Education is an effective combination of education and technology, new technologies, and continue to apply in all areas of education, so educational technology has distinct characteristics of the times. In fact, as science and technology, media technology continues to progress, education, information technology has penetrated into all areas of society transition period, the field of education and technology enterprises, training, information technology, information resources more closely related to educational technology field of employment of graduates and to be greatly expanded. A few days ago, the new field of educational technology courses can not be timely to meet the educational technology, such as virtual reality, intelligent technology, performance, knowledge engineering, knowledge management and other needs.

Table 3 Majors body language skills Education Survey

\begin{tabular}{|c|c|c|c|}
\hline topic & Reply & Quantity & percentage(\%) \\
\hline Is there a teaching & Often & 52 & 12.2 \\
process & Occasionally & 330 & 77.6 \\
Trick out & No & 43 & 10.2 \\
& Natural wealth & 232 & 54.6 \\
\hline Teaching facial & Less natural wealth & 145 & 34.1 \\
expressions & Single flat & 32 & 7.5 \\
& Exhibit tension & 16 & 3.8 \\
\hline Classroom with eyes & Regular exchange of & 342 & 80.4 \\
And in the case of & Occasionally exchange & 83 & 19.6 \\
student exchanges & No AC & 0 & 0 \\
\hline
\end{tabular}

Recently a number of open educational technology professional schools, nearly two years accounted for more than half of the new start-up, along for the conventional school system, teaching targeted is not strong, there is no character. Performance in teaching is to impart theoretical knowledge in the first place, and the practice of teaching, capacity-building supplement in the form of reason perish as imparting knowledge, teaching practice is relatively weak. In the traditional view of the constraints, the school in the capital, with teaching resources, teaching content and 
teaching methods use _l select few, have a tendency to theoretical classroom teaching, so that teaching practice in a secondary position.

Teachers in the classroom to instill a lot of knowledge, but students in school basically no chance to practice and apply their theoretical knowledge. Educational technology curriculum system even after several adjustments and continuous improvement, there are still a few days ago orientation of training basic reason perish educational technology, educational applications of information technology, education, information technology, education, information management, remote education, cloud \#\} computer applications, film and television festival director and production, television systems, digital media technology. Due to the continuous application of new technologies in various fields of education, teaching public class Ge Japan limits curricular teaching more content, classroom time is short, unable to penetrate teaching students in the classroom root wood no chance to practice with the application of knowledge.

\section{Reason Education Students' Teaching Practice Ability}

Training Patterns Reasons. "Training Mode Training Mode or school students to build knowledge, capability, quality construction, and implementation of such a structure, which defines the characteristics of talent and focus reflects the ideas and concepts of education fundamentally. Briefly the training mode is actually training objectives of talent, training specifications and basic training methods. "training model plays an important role in the process of personnel training, due to the different levels of education requirements for teachers are not the same, the training mode it should also be different. Unlike education secondary education, it has its own characteristics, and therefore, teacher training model should also be different from the training mode of middle school teachers. But now, on the one hand due to the professional education in a number of teachers colleges, especially the professional bachelor degree education is a relatively new profession, the development is still immature, lack of appropriate experience in the training of teachers, is still in the "learning practice while research side of the building ", it did not establish curriculum system and the formation of cultural and professional characteristics of teachers education. Therefore, the actual need to consider such as less education appear in the training process, the lack of specific training programs developed by other issues, resulting in training mode are blind, trained teacher quality is not high. On the other hand, some teachers colleges still follow patterns to train secondary school teachers training teachers, teachers appear "secondary school teachers" of bias. Mr. Gu Mingyuan also clearly states: "In recent years, teacher education reform agencies carried out very rapidly, and the professional level of teachers did not have much to improve ...... What are the consequences of these changes are too extreme right some more radical is weakened.? the teacher education system, reducing the professional level of teachers, which is the biggest loss of teachers.

Cause of educational theory courses.

Cause of Educational Theory. Courses.Throughout the course structure, curriculum and has enjoyed high status, and best embodies the characteristics Normal Normal Universities also teaching students practical ability of the core curriculum but lack of attention to educational theory, lower status in the curriculum structure. In addition, class lessons and other educational curriculum of theoretical courses compared with far smaller proportion of the total hours, and foreign education courses across the curriculum structure, but there is a percentage is compared large gap, in such circumstances, higher teacher education students can not study and education systems theoretical knowledge of science, will inevitably affect the ability to develop their teaching practice.

Educational theory course is teaching students to master the main source of educational theory, but the current knowledge of education theory course Teachers Education opened old, especially small and basic education curriculum reform linked. As a future teacher, the school master after some of the relevant theoretical knowledge of basic education curriculum reform in education the basis and premise. However, through questionnaires learned Teachers Education Majors understanding of the basic education curriculum reform is not high, when the students were interviewed, many students expressed not involve basic education curriculum reform related knowledge in textbooks, teachers in the lecture course also no system to explain before, but rough mentioned. 
"Lessons are expressed verbally teacher teaching specific topics envisaged its theoretical basis, which is the basis of preparation of the instructor on the face peers or faculty members about their instructional design and comment by the listener, to communicate with each other, common a teaching and research activities of teacher training purposes to improve. " as a teaching and research activities, Lessons due to restrictions by time, space and the number of teachers in a short time to allow Lessons own understanding of curriculum standards the students learn to understand the situation, the whole classroom teaching design, teaching methods and means of selection and application content such articulate, and let those who understand how to teach lectures, why this teaching, which is largely help to improve the quality of teacher preparation and teachers' practical ability. However, at present, Lessons in Normal Colleges and training is not very seriously. In the interview, when asked "Do you participate Lessons training times", many students expressed only participated in two or three times Lessons training, showing that the number of Lessons in Teachers College training is not a lot. And when asked "Do you think what are the problems Lessons Activities", many students said "lack of guidance on the activities Lessons, Lessons do not know how."

\section{Training Strategy of Student Teaching Practice Ability}

Optimized Model and Normal School Reference Features. After the 1980s, with the development of our economy and society, as comprehensively promote the reform of basic education, teacher qualifications and quality have become increasingly demanding. From the mid-1980s, China began test specialist qualifications teacher training. In the late 1990s, he began to explore undergraduate degree in Teacher Training. After entering the new century, as China's normal education system from three to two transition teachers fully integrated into the higher education system, highly educated teacher training pace faster and faster. However, after entering the field of higher education teacher culture, especially in the undergraduate level, due to changes in enrollment targets and training methods, and some middle stage of Teacher Education of distinctive and effective training methods are gradually fade, especially for student education Training the practical ability, often caused by inadequate attention many students do not know how to teach after graduation. Some original upgraded from the Secondary Teacher colleges, colleges due to the rush to close to its original characteristics of normal school, especially in terms of the characteristics of practical ability of students teaching, but also gradually fade and disappear. Therefore, learn the characteristics of normal school, especially for the education of students practical ability emphasis characteristics, so as to train more qualified teachers.

Optimization Theory Course Structure Education and Reform of Teaching Methods. As we all know, the development of knowledge and ability to master closely linked. Mastery of knowledge is the basis and prerequisite for capacity development, and in turn promote the development of the ability to master knowledge. Therefore, to make primary school education majors have a strong teaching practical ability, must first be allowed to possess a wealth of theoretical knowledge education. However, there are a lot of primary school education professional theory courses offered limited kind of education, and in particular the lack of pupils, primary education is closely related to teaching theoretical courses, which allow students to grasp just some rigid theoretical knowledge, lack of appropriate applicability. Thus, primary school education to enrich the professional education curriculum theory, in particular, to add some pupils, primary education is closely related to the content of education to enable students to expand horizons, to form a more comprehensive, solid, practical and theoretical knowledge. Meanwhile, for the Theory of Education underprivileged lower class of proportions, primary school education professional to re-formulate lesson plans, curriculum theory to increase the number of hours of education, so that education theory courses occupy a suitable proportion of the total curriculum. In this regard, we can learn from the experience of developed countries. Further, in the actual classroom teaching process, to formulate relevant measures to ensure the Theory of Education in accordance with the number of hours performed.

Strengthening Skills Training to Enhance Awareness of the Role. Aesthetic education, sports, 
labor and technical education is an important part of the comprehensive development of education students, as teachers, we should have the appropriate art and physical labor and other skills. On the one hand, students are in the body a long time, they are energetic, lively, like cultural and sports activities, art and physical labor to master the knowledge and skills conducive to entertaining, the students comprehensive education. On the other hand, teaching is an art, art and physical labor are also art, since it is art, a lot of things are interlinked. For example, offer music lessons to improve students' grasp of rhythm throughout the classroom teaching ability, the creation of art classes to improve students' ability to design and writing on the blackboard layout, etc. Therefore, art and physical labor skills help improve students' ability of teaching practice. Previously, normal school teachers trained stage reason is very popular, too, and they sing and dance in the classroom, teaching the art and fully integrated related. Primary Education Teachers Colleges to strengthen the students' attention to art and physical labor skills and training. First, the creation of art and physical aspects of labor-related courses, and as a required course in the curriculum plan in the past. Second, teachers with specialized training and guidance for students; again, develop appropriate assessment criteria, the students of art and physical labor skills assessment is also included in the scope of examination. Finally, carry out a variety of extra-curricular activities to strengthen students' art and physical training and improve labor skills.

\section{Summary}

Educational Technology Major is a technical, highly practical emerging professional practice of educational technology majors lack of capacity development, which reflects our colleges and universities, there are some shortcomings in the education of technical personnel training, and how to overcome these deficiencies, society needs to cultivate education and technical personnel, we are constantly thinking and to explore the issue.

\section{Acknowledgment}

Project: "Improve Practical Methods and Effective Way of Educational Technology Majors"; School level project.

Project No.: 1076514139

\section{References}

[1] Barab, S.A., MaKinster, J.G.Moore, A.etal. Designing and building an on-line Community: The struggle to support sociability in the inquiry learning forum.ETR \& D, 2001,49 (4): 71- 96.

[2] Barber, M. Reconstructing the teaching of session. Journal of Education for Teaching [J]. 1995,21 (1): 75-85

[3] Brian Mulligan:? A New Cost Model for Distance Edueation in Europe [J]. .http // www.chinaonlineedu.com/yuanwen/special.asp id = 137?.

[4] M.G. Moore \& G.Kearsley. Distance Education: A system view [M]. Belmont, CA:. Wadsworth1996

[5] Roger Mills. Quality assurance in distance education-towards a culture of quality: a case studyof the Open University, United Kingdom (OUK) [DB/OL] www.col.org.

[6] Kang, M. \& Kwon, Y.A Conceptual Framework for a Web-Based Kowledge Construction Support System [J]. Educational Technology 2001.Vol.41, No.4.

[7] Travers, R.M.W., The Teacher as a Performing Artist. The Education Digest, January1980 [8] Ross, D. D. First Steps in Eloping: A Reflective Approach Journal of TeacherEducation.40 (2) .22-30.

[9] Hirs, R.H., Edueation Theory. In First, P.H. (Ed.), Edueational Theoryand Its FoundationDisciolines, 1983.

[10] Moller. L. Designing communities of learners for asynchronous distance Education. Educational Technology Research \& Development.1998, 46 (4), 115-122. 
[11] Gunawardena, C., C. Lowe, and T. Anderson. Analysis of a global online debate and the development of an interaction analysis model for examining the social construction ofknowledge in computer conferencing Journal of Educational Computing Research 1997.17 (4).: 397-431. 